\title{
Sustainable development: beyond appearances
}

\author{
Tatiana Dănescu' ${ }^{1}$, and Radu Bogdan Matei* \\ ${ }^{1}$ University of Medicine, Pharmacy, Science and Technology „G. E Palade” Tg. Mures, Street \\ Marinescu Gh, no.38, 540139, Romania \\ ${ }^{2}$ University „1 December 1918” Alba Iulia, Street Gabriel Bethlen, no.5, Alba Iulia, 510009, Romania
}

\begin{abstract}
Global resilience and stability have produced changes in the collective mentality, aimed at developing the spirit of resource conservation, increasing the quantity of recycled materials with effects in reducing climate change. The interdependence between economic, environmental and social considerations for ensuring sustainable development is obvious, their trend being of real interest in current research, because like those presented in the Brundtland report, only this will ensure "the needs of current generations without compromising the possibility of future generations to satisfy their own needs". Based on a cascading research, from the global approach to sustainable development, to the practices reported by entities in Romania in the last five years, we aim to take stock of the achievements to identify where we are currently compared to the global target launched through the 17 sustainable development goals set by the UN in the 2030 Agenda.
\end{abstract}

\section{Introduction}

The concept of sustainable development is considered one of the most relevant topics nowadays. This concept is primarily based on protecting the environment and ecosystems, responsible consumption and avoiding the overexploitation of limited natural resources. The sustainable use of resources must be carried out in a manner and periodicity that does not affect their existence, thus maintaining the properties necessary to meet the future needs of the population.

Sustainable development appears in the context of global demographic changes and the scarcity of natural resources, aiming at the balance between the $3 \mathrm{E}$, economic, ecological and ethical (social) foreshadowing a "triangle of sustainability". Taking into account the analyzes carried out by demographic experts, the population will reach a level of saturation in about 30 years, so even in conditions of zero impact on the environment, the available resources will no longer be sufficient [1].

The principle of sustainable development must not only be applied by multinational companies and central public institutions, in order to maximize the impact, it is the duty of each of us to protect the environment and society for future generations, because acting as „responsible citizens" can achieve the phrase ,think globally, act locally”.

Social problems have worsened with the uneven development of countries, so there are areas of risk that remain undeveloped. Agenda 2030 states that "no one will be left behind",

\footnotetext{
* Corresponding author: radubogdanmatei@gmail.com
} 
with developed countries providing official assistance to achieve a balance. This agenda is based on the implementation of the 17 objectives and 169 targets, and the National Sustainable Development Strategy uses a number of 88 targets for the time horizon 2020 and 104 for 2030, the general trend being towards convergence, having common points, moving towards for the same purposes.

Considering that the investors are more and more interested in the transparent information presented in the sustainability reports, companies management must turn their attention and strategy towards social responsibility actions, profit maximization not being the only objective of an efficient business.

\section{Defining the researched problem}

The term „sustainable development” was introduced in the mid-1970s by Lester Brown in his work "Plan B 2.0" which drew attention to the conflict between the ecosystem and industrial civilization, the most important aspects being: deterioration of essential environmental factors, resource consumption in -a much faster pace than the possibility of regeneration and the growing tendency to deplete natural resources, food, water and air [2].

The current global crisis caused by the Sars-Cov 2 virus has a significant impact on the 17 SDGs, creating many uncertainties. However, there are also some opportunities, which should be considered because there is a link between frequent environmental changes and the occurrence of infectious diseases. The urgent need for a long-term strategy is obvious, thus improving the health of the population, leading to sustainable development. [3].

\subsection{The object of sustainable development}

The concept of sustainable development determines a link between the natural environment and sustainability, while also involving certain subsequent factors such as: national security and peace, biodiversity protection, energy efficiency, social and digital inclusion [4]. Sustainability requires a holistic approach to economic, social and natural aspects [5], combining various fields of activity: ecology, sociology, marketing and economics [6].

In 1987, the World Commission on Environment and Development published the report "Our Common Future", also known as the Brundtland Report, in gratitude to the Prime Minister of Norway. Through this manifesto, the term sustainable development was established and the most well-known, taken and cited definition was offered. Sustainable development "pursues the needs of the current generation, without compromising future generations' ability to meet their own needs" [7]. The last century has been marked by obvious economic progress around the world, but side effects have also occurred quite normally: uncontrolled environmental pollution, the intensity of climate change exacerbated by greenhouse gas emissions and global warming. Initially, sustainable development focused on the environmental movement for environmental conservation. Along the way, it spread to society, developing targets for public health, hunger and poverty. [8]. With the advent of this report, sustainability is considered an issue of global importance, being considered the greatest challenge of the 21st century.[9].

Representing a premise of the corporate social responsibility activity, the voluntary sustainability action carried out more and more often by the national companies is considered an efficient way of integration in the business strategy. [10]. Interest is very high lately both from academia and from the Government and the local community, exponential development based on innovation, entrepreneurship, economic and social progress, focused on quality of life and life expectancy. [11]. Romania faces a number of problems that affect sustainable development. Multinational companies being influenced by the parent company address 
social and environmental issues without having legal obligations, thus offering a possibility to solve previous problems [12].

The implementation of the medium- and long-term sustainability strategy, the social and environmental aspects, the interdependence between them and the voluntary nature of these actions, are considered a marketing innovation. Companies are thus much more attentive to stakeholders, informing them about the efforts made to reduce the impact on the environment, the proactive approach to social inclusion and giving them the opportunity to make decisions through the sustainability matrix. [13]. The key features of sustainable development are [14]:

- Equity - represented by the correct distribution of costs and benefits between nations;

- Long-term approach - the needs of future generations are taken into account taking into account the limited resources of the planet;

- Systemic thinking - presented by the complex interaction between existing subsystems and the interdependencies between society, environment and economy.

Considered a key platform for communication between the community and the population, sustainability has an impact on national companies, with reporting practices having a number of benefits such as: comparability, fair evaluation, efficient management, increased productivity and efficiency, access to the capital market and meeting stakeholder expectations.

The transition from the 8 Millennium Development Goals to the 17 Sustainable Development Goals exponentially reflects the evolution of discourse in this area. The key strategy imposed by this change is "governance by objectives", currently not implemented in all countries. [15].

In order to find an interconditionality between ecological and economic systems, a comprehensive approach is needed on 3 highly relevant areas, each with a distinct approach: circular economy, green growth and specific research. The circular economy is one of the most ubiquitous concepts in sustainable development and essentially suggests increasing resource efficiency to improve the balance between the economy, society and the environment. [16].

\subsection{Research methodology}

Cascading empirical research has been developed by studying the sustainability reports of companies in the United Nations Global Compact (UNGC) database. There are 19 companies in Romania in this database, all respecting the 10 UNGC principles, thus providing support for the harmonization of business strategies in the field of environment, work practices, human rights and anti-corruption. The organization is the main promoter for achieving the 17 Sustainable Development Goals (SDGs). The main objective of the research is to take stock of the achievements in Romania, in order to identify where we are at the moment compared to the global target launched by Agenda 2030 by the UN. To stage the research, we set related objectives: identifying and analyzing the practices reported by entities in the last five years from the sustainability / non-financial reports of companies in the UNGC database, determining whether the 3 sides of the sustainability triangle - economics, ecology and ethics - are inter - conditioned, and the modification of one influence the modification of the others.

The research was applied to companies exceeding the average number of 500 employees and published a non-financial report for the period 2015-2020. Of the 19 companies, only 5 of them met all the criteria, so the research was focused on the 2019 reports published on the company's or UNGC's own website. 4 research areas were set, 21 indicators totaling 105 items. The scoring scale is between 0 and 1 , the score given being 0 points if no information about the researched indicator is presented, 0.5 points if it is presented only partially and 1 
point if the information presented is considered exhaustive. For the statistical modeling of the obtained data, we used the software Eviews 11 and Microsoft Excel.

The proposed research hypotheses to be tested by empirical study were the following:

- Does Romania present an advanced level of fulfillment of the SDGs 5 years after the launch of the 2030 Agenda?

- Is there a link between sustainability reporting and profitability rates of the companies analyzed?

- Is there a data, between the 3 dimensions of sustainability?

\section{Presentation of research results}

For the 17 SDGs and the National Strategy, we highlighted targets for each of them and conducted an analysis during the 5 years since the implementation of the European Agenda. The SDGs are grouped into 4 categories, namely:

- Social Domain (Objectives 1,2,3,4) - the situation at national level is not at all encouraging, the targets are far from being reached. Although Romania is considered to have overcome the problems related to poverty and hunger, $23 \%$ of the population still lives in relative poverty. As for investments in school infrastructure, they are at a very low level, considering that the GDP allocated in this sector being only $3.2 \%$, a value that places us at the end of the ranking in the EU. School dropout during the analyzed period increased by $1 \%$, a situation that will generate an increase in unemployment, relative poverty, exclusion from an economic, social and digital point of view. Life expectancy is the only target in this sector that has evolved favorably, changing by 1.1 years;

- Governance and Human Rights (Objectives 5,10,16,17) - the situation in this area is significantly better than before, most targets being close to fulfillment. Gender equality is close to the EU average, $35 \%$ of the staff with management positions in Romania are occupied by women. Foreign direct investment increased by about $50 \%$ compared to 2015 and donations for official development assistance doubled in value. The only negative indicator is the population growth, the country's population decreased by almost 1 million inhabitants during the analyzed period;

- Environment (Objectives 6,7,13,14,15) - the share of energy from renewable sources in 2020 was $24.3 \%$ with 5 percent above the EU average which aims to transition to a green and sustainable economy to thus becoming energy neutral. The connection rate to water and sewerage infrastructure has diametrically opposed values between urban and rural areas. In urban areas the situation is favorable, the rate being over $95 \%$, but in rural areas it is only $35 \%$, ranking us in the last positions in the EU, the main causes being: low population density and population affordability. The forested area of the country is below the EU average, but a favorable aspect is the implementation of the "Forest Inspector", a digitized system for monitoring timber exploitation and transport;

- Economic Domain (Objectives 8,9,11,12) - in 2020, Romania was among the first places in the EU in terms of GDP growth rate, located at $4.1 \%$. The situation is worrying regarding the number of deaths from road accidents, 96 people per million inhabitants, the causes being the road infrastructure, the lack of highways. Also, spending on research, development, innovation is well below the EU average during the reporting period.

The empirical research applied on the sustainability / non-financial reports of the companies was carried out for 2019, using both general information and economic, social and environmental information. Regarding the general information that was used in the study, we find the following: the type and number of reports published during the reporting period, the notions of social responsibility on each company's website, the message from the CEO on sustainability, the standards by which they were guided in preparing the report and 
auditing the information presented. The level of progress communicated by the UNGC on the basis of the evaluation of the reports presented was also taken into account (Table 1).

Table 1. Presentation of the analyzed companies from the UNGC database.

\begin{tabular}{|c|l|l|c|c|c|c|c|c|}
\hline $\begin{array}{c}\text { Crt. } \\
\text { No. }\end{array}$ & $\begin{array}{c}\text { Company } \\
\text { name }\end{array}$ & Report type & $\begin{array}{c}\text { No. } \\
\text { reports }\end{array}$ & Site & CEO & Standards & COP & Audit \\
\hline $\mathbf{1}$ & LIDL Ro & $\begin{array}{l}\text { Sustainability/ } \\
\text { Non-finan. Decl }\end{array}$ & 1 pct & $1 \mathrm{pct}$ & $1 \mathrm{pct}$ & $1 \mathrm{pct}$ & $\begin{array}{c}\text { Advanced } \\
1 \mathrm{pct}\end{array}$ & $1 \mathrm{pct}$ \\
\hline $\mathbf{2}$ & Telekom Ro & CSR & $1 \mathrm{pct}$ & $1 \mathrm{pct}$ & $1 \mathrm{pct}$ & $0 \mathrm{pct}$ & $\begin{array}{c}\text { Active } \\
0,5 \mathrm{pct}\end{array}$ & $0 \mathrm{pct}$ \\
\hline $\mathbf{3}$ & $\begin{array}{l}\text { Advanced } \\
\text { Technol. }\end{array}$ & $\begin{array}{l}\text { UNGC } \\
\text { Communications }\end{array}$ & $0,5 \mathrm{pct}$ & $\begin{array}{c}0,5 \\
\mathrm{Pct}\end{array}$ & $1 \mathrm{pct}$ & $0 \mathrm{pct}$ & $\begin{array}{c}\text { Active } \\
0,5 \mathrm{pct}\end{array}$ & $0 \mathrm{pct}$ \\
\hline $\mathbf{4}$ & $\begin{array}{l}\text { OMV Petrom } \\
\text { Sustainability }\end{array}$ & $1 \mathrm{pct}$ & $1 \mathrm{pct}$ & $1 \mathrm{pct}$ & $1 \mathrm{pct}$ & $\begin{array}{c}\text { Advanced } \\
1 \mathrm{pct}\end{array}$ & $0,5 \mathrm{pct}$ \\
\hline $\mathbf{5}$ & $\begin{array}{l}\text { Unilever } \\
\text { S.C.E }\end{array}$ & $\begin{array}{l}\text { Sustainability } \\
\text { plan }\end{array}$ & $0 \mathrm{pct}$ & $1 \mathrm{pct}$ & $1 \mathrm{pct}$ & $0 \mathrm{pct}$ & $\begin{array}{c}\text { Advanced } \\
1 \mathrm{pct}\end{array}$ & $0 \mathrm{pct}$ \\
\hline
\end{tabular}

In table no. 1, can be observed the general information regarding the 5 companies used, that resulted from the analysis of the non-financial reports. The company LIDL Ro is the only one that published a sustainability report accompanied by the non-financial statement, which specifies the financial year different from the classic one. It is the only report audited by a third-party company, which has ensured that the information presented is correct and free from material errors. GRI Core, AA 1000, ISO 26,000 are the standards used to write the 84page sustainability report. Telekom Ro published annual social responsibility reports, and in 2019 it was included in the Gold CSR Index category. The report comprises 44 pages, is prepared based on the Romanian legislative requirement (O.M.F.P no. 3456/2018) and has not been audited. Advanced Technologies publishes an annual progress report to UNGC demonstrating transparency and a penchant for sustainable development, influencing business partners to reduce their impact on the environment and reject all forms of corruption. In 2015, he received the Gold Level distinction from the CSR Romania agency. Note the effort, taking into account that the average number of employees did not exceed 20. OMV Petrom is the longest-lived in the field of sustainability, voluntarily publishing annual reports from 2011 to date, responsibility practices being part of the company's DNA. The existence of the report was verified by the audit company, proposing that future publications be audited and realized through consultancy. Responsible business practices and social actions are published on the company's website, where information on the "Petrom 2025 Sustainability Strategy" can be found. Unilever South Central Europe was analyzed globally because the group in Romania does not meet the size requirements. The report was based on a 10 -year sustainability plan proposed by the company, no information was published on the standards used and the audit. The site is very comprehensive, the interest for sustainable development being highlighted by reducing climate change, social inequality, improving the quality of life and health of employees.

The information analyzed in terms of environmental protection was based on 4 standard indicators found in the non-financial reports: environmental management policy, energy efficiency and responsible energy consumption, the amount of GHG emissions and sustainable waste management. LIDL Ro and OMV Petrom have published the most transparent information regarding the company's policy to protect the ecosystem. The first of these adopted the Plastic Reset Strategy, thus excluding disposable plastic items, and 
packaging is $100 \%$ recyclable. To increase energy efficiency, all spaces are equipped with LED lighting systems (16\% reduction in the amount of energy consumed). In collaboration with an environmental association, it has implemented the "Drona Waste Shark" project, a floating waste management system that can collect 500 kilograms per day. At the level of OMV Petrom, investments and environmental reporting are made according to the Environmental Management Accounting methodology, which denotes high transparency in the published information. GRI reporting is also used, with direct and indirect GHG emissions falling significantly from the previous year. It should be noted that all companies are ISO 14001 certified, resulting in a major interest in reducing the negative impact on the ecosystem.

Given the importance of attention to social inclusion, we considered the following relevant issues: respect for human / employee rights, respect for gender equality and women's empowerment, volunteering and the introduction of codes of conduct to prevent corruption. The company's involvement in achieving the sustainable development objectives was also analyzed. The "Safe Harbor" principle was applied to highlight the negative aspects, the disadvantages that a company could have if it presents information in non-financial reports on accidents at work, conflicts with employees or in business relations and lawsuits (Table 2).

Table 2. Social criteria used in empirical research.

\begin{tabular}{|c|l|c|c|c|c|c|c|}
\hline $\begin{array}{c}\text { Crt. } \\
\text { no. }\end{array}$ & $\begin{array}{c}\text { Company } \\
\text { name }\end{array}$ & HR & $\begin{array}{c}\text { Gender } \\
\text { equality }\end{array}$ & Volunteering & Corruption & $\begin{array}{c}\text { Negative } \\
\text { aspects }\end{array}$ & ODD \\
\hline $\mathbf{1}$ & LIDL Ro & $0.5 \mathrm{pct}$ & $0.5 \mathrm{pct}$ & $1 \mathrm{pct}$ & $0.5 \mathrm{pct}$ & $1 \mathrm{pct}$ & $0.5 \mathrm{pct}$ \\
\hline $\mathbf{2}$ & Telekom Ro & $1 \mathrm{pct}$ & $1 \mathrm{pct}$ & $1 \mathrm{pct}$ & $1 \mathrm{pct}$ & $1 \mathrm{pct}$ & $1 \mathrm{pct}$ \\
\hline $\mathbf{3}$ & $\begin{array}{l}\text { Advanced } \\
\text { Technol. }\end{array}$ & $0.5 \mathrm{pct}$ & $0.5 \mathrm{pct}$ & $0 \mathrm{pct}$ & $0.5 \mathrm{pct}$ & $0 \mathrm{pct}$ & $0.5 \mathrm{pct}$ \\
\hline $\mathbf{4}$ & OMV Petrom & $1 \mathrm{pct}$ & $1 \mathrm{pct}$ & $1 \mathrm{pct}$ & $1 \mathrm{pct}$ & $1 \mathrm{pct}$ & $1 \mathrm{pct}$ \\
\hline $\mathbf{5}$ & Unilever S.C.E & $0.5 \mathrm{pct}$ & $1 \mathrm{pct}$ & $0 \mathrm{pct}$ & $0 \mathrm{pct}$ & $0 \mathrm{pct}$ & $1 \mathrm{pct}$ \\
\hline
\end{tabular}

The research approaches took into account 6 social criteria, presented in Table no. 2 , these being in direct accordance with the 10 UNGC Principles. According to the information published in the sustainability reports, Telekom Ro has internally adopted a Code of Rights and Social Principles, which assumes respect for human rights and rejects any discrimination in the workplace, promotes equal opportunities and diversity of employees. $42 \%$ of the company's employees are female, and the pay ratio between the two sexes is 1: 1. Through its own strategy, OMV Petrom aims to increase the proportion of women in management positions to over $30 \%$ by 2025, an objective correlated with European practices. Through the environmental incident published in the report, oil spills that affected a considerable area of land, denotes commitment, responsibility and transparency towards stakeholders. All the analyzed companies published information on how their activity supports the fulfillment of the 17 SDGs.

In the economic field, the key indicators used in the research were: the transparency of sponsorships, the risks to which the company's activity is subject and the amounts invested in social responsibility and sustainable development actions. During the reporting period, OMV Petrom supported over 170,000 social causes in the field of culture, sports, education, but also health, contributing with 10 million Euros for the construction of an oncology hospital. The materiality matrix of Lidl Ro highlighted the main areas of risk: cash operations, corruption, employee remuneration, sustainability (Table 3 ).

According to the reasoning used in the audit practice (compliance level), we set accountability / transparency thresholds as follows:

- Over 75\% - high level of transparency; 
- Between 50\% -75\% - average level of transparency;

- Below 50\% - low level of transparency.

Table 3. The total score achieved by the analyzed companies.

\begin{tabular}{|c|l|c|c|c|c|c|}
\hline $\begin{array}{c}\text { Crt. } \\
\text { no. }\end{array}$ & Company name & General & Environment & Social & Economic & $\begin{array}{c}\text { Total } \\
\text { score }\end{array}$ \\
\hline $\mathbf{1}$ & LIDL Ro & $7 \mathrm{pct}$ & $4 \mathrm{pct}$ & $4 \mathrm{pct}$ & $2,5 \mathrm{pct}$ & $\begin{array}{c}17,5 \mathrm{pct} / \\
83 \%\end{array}$ \\
\hline $\mathbf{2}$ & Telekom Ro & $4,5 \mathrm{pct}$ & $3,5 \mathrm{pct}$ & $6 \mathrm{pct}$ & $3,5 \mathrm{pct}$ & $\begin{array}{c}17,5 \mathrm{pct} / \\
83 \%\end{array}$ \\
\hline $\mathbf{3}$ & $\begin{array}{l}\text { Advanced } \\
\text { Technol. }\end{array}$ & $3 \mathrm{pct}$ & $1,5 \mathrm{pct}$ & $2 \mathrm{pct}$ & $0,5 \mathrm{pct}$ & $7 \mathrm{pct} / 33 \%$ \\
\hline $\mathbf{4}$ & OMV Petrom & $6,5 \mathrm{pct}$ & $4 \mathrm{pct}$ & $6 \mathrm{pct}$ & $4 \mathrm{pct}$ & $\begin{array}{c}\mathbf{2 0 , 5} \mathbf{~ p c t} / \\
\mathbf{9 7 \%}\end{array}$ \\
\hline $\mathbf{5}$ & Unilever S.C.E & $3,5 \mathrm{pct}$ & $2,5 \mathrm{pct}$ & $2,5 \mathrm{pct}$ & $1 \mathrm{pct}$ & $9 \mathrm{pct} / 45 \%$ \\
\hline
\end{tabular}

From the analysis performed according to the applied research methodology, as it results from Table no. 3, OMV Petrom obtained the best score, 97\%, the only points lost were regarding the lack of auditing the sustainability report. On this basis, we conclude that it is the most transparent and responsible company from an economic, social and environmental point of view. LIDL Ro and Telekom Ro also achieved a high level of transparency, both by $83 \%$. There is no company with a medium level of transparency. Unilever S.C.E obtained $45 \%$, being analyzed globally. The last ranked was Advanced Technologies with $33 \%$, given that during the reporting period the average number of employees did not exceed 20 people, and the costs involved in such reporting are much higher than the benefits.

To test the hypothesis of a link between the company's transparency and its profitability, we used the rates of commercial (ROS), financial (ROE) and economic (ROA) profitability. Telekom Ro was excluded from this analysis, as it did not calculate profitability rates during the reporting period (Figure 1).

\begin{tabular}{c|rrrr}
\hline \hline $\begin{array}{c}\text { Correlation } \\
\text { Probability }\end{array}$ & CSR & ROA & ROE & ROS \\
\hline CSR & 1.000000 & & & \\
& - & & & \\
ROA & 0.739897 & 1.000000 & & \\
& 0.2601 & - & & \\
ROE & 0.630729 & 0.910051 & 1.000000 & \\
& 0.3693 & 0.0899 & - & \\
ROS & 0.654622 & 0.474706 & 0.093834 & 1.000000 \\
& 0.3454 & 0.5253 & 0.9062 & - \\
\hline \hline
\end{tabular}

Fig. 1. The correlation matrix between corporate social responsibility and profitability rates. Source: authors' research using Eviews 11.

There is a positive correlation between the analyzed elements, so any increase of one element will influence the favorable change of the others. The relationship between the company's social responsibility and the ROA, measured by Pearson's correlation coefficient $\mathrm{R}$, is 0.739 , the degree of association determining a strong correlation. There is also a correlation between ROE, ROS and the informational transparency of the analyzed companies, the degree of association being moderate, 0.630 , respectively 0.654 . 


\section{Conclusions}

Multinational companies are the ones that brought the first social responsibility programs in the business sphere. It is necessary for Romanian entities to be guided by positive examples and to carry out actions of social inclusion, protecting the environment for purely ethical reasons, not using such opportunities only for advertising, marketing, and to attract new customers. Therefore, social responsibility is a premise of sustainable development that generates long-term profitability.

Regarding the situation of sustainable development objectives and targets in the 2030 Agenda, according to information published in Romania and at the level of companies studied, taking into account that 5 years have passed since the implementation, the balance is not very favorable, placing us in last place from the European Union for many sectors. School dropout rate, lack of investment in basic infrastructure (water, sewerage, road, education, health), low share of spending on research and development, number of people living in relative poverty, demography, low degree of selective collection and recycling products are aspects to be considered because they will directly affect sustainable development, social and digital inclusion of the population, will generate unemployment and health problems. The favorable aspects should be highlighted, Romania being among the first places in the European Union in terms of GDP growth, the share of energy from renewable sources, foreign direct investment, gender equality and women's emancipation. Based on the results obtained from the study, we consider that the degree of achievement of the objectives in Romania is not currently obtained, but there are reasons for hope that in the remaining 10 years, the situation will improve significantly, the research hypothesis being refuted at the time of analysis.

According to the analysis, 3 of the 5 companies, based on the information published in the sustainability reports, have a high level of compliance with social responsibility requirements. The research hypothesis on the existence of a causal relationship between profitability rates and corporate social responsibility is confirmed. The link between rates of return and corporate social responsibility is positive, with the values of Pearson's $\mathrm{R}$ coefficient demonstrating a strong correlation between the defined elements. Thus, we consider that, if the management of companies focuses on carrying out social responsibility actions in purely ethical conditions, they will attract new customers and investors, improve productivity, and subsequent results will be visible in turnover and profit. financial.

Although, the term development was initially used only for the economic part, the only implication being the company's profit, the situation changed radically. With globalization and industrialization, environmental issues, climate change and energy efficiency have emerged, actions that have received special attention. According to the results of the research, the 3 sides of the triangle of sustainability, economics, ecology and ethics, are interconditioned and any increase of one will influence the favorable change of the others. Through the data obtained in the empirical research, the hypothesis of interconditioning the dimensions of sustainability are confirmed.

\section{Refernces}

1. M. Lupascu, Characteristics and essence of sustainable development of the territory and community development, Admin. publ., 2, (106), 109-113, (2020)

2. L. Brown, Plan B 2.0. Saving a planet under pressure and a deadlocked civilization, (Bucharest, Technical Publishing House, 2006)

3. R. Feuner, T. Cernev, The implications of the Covid-19 pandemic for delivering the Sustainable Development Goals, Futures, 128, 1-12, (2021)

4. A. Stere, I. Popa, S. Cotescu, Substantiation of the concept of sustainable development, EEA, 62, (2), 112-123, (2014) 
5. M. Bejan, T. Rusu, Exploitation of natural resources and the concept of sustainable development, AGIR Bulletin, 1, 20-24, (2007)

6. I. Serageldin, M. Cohen, J. Leitmann, Enabling sustainable community development, (Washington, World Bank, 1995)

7. WCED, Our Common Future. Brundtland Report, (London, Oxford University Press, 1987)

8. B. Voicu, Social Capital as a Premise of Sustainable Development, Quality of Life, XIX, (1), 85105, (2008)

9. A. Eremia, I. Stancu, Banking for sustainable development, Econ. t.a., 6, 23-32, (2006)

10. A. Stancu, M. Orzan, Social responsibility of Romanian companies - a step for sustainable development, Revista de Mark.O, 1, (2), pp. 49-53, (2006)

11. M. Kardos, The Relationship between Entrepreneurship, Innovation and Sustainable Development. Research on European Union Countries, Procedia E\&F, 3, pp. 1030-1035, (2012)

12. T. Dănescu, M. Popa, Public health and corporate social responsibility: an exploratory study on pharmaceutical companies in an emerging market, Glob. \& Heal., 16, (117), pp. 1-9, (2020)

13. V. Popa, E. Cara, The impact of the innovation process on sustainable development strategies and policies, Journal Econ., 1, (3), pp. 7-21, (2020)

14. C. Ciupagea, D. Manoleli, V. Niță, M. Papatulică, M. Stănculescu, Strategic directions of sustainable development in Romania, (Bucharest, European Institute of Romania, 2006)

15. E. Joug, M. Vijge, From Millennium to Sustainable Development Goals: Evolving discourses and their reflection in policy coherence for development, Earth Sys. Gover., 7, pp. 1-12, (2021)

16. L. Urena, J. Ubeda, D. Brust, N. Yakovleva, Circular economy, degrowth and green growth as pathways for research on sustainable development goals: A global analysis and future agenda, Ecol. Econ., 185, pp. 1-17, (2021) 